\title{
Da Legeforeningen var 100 år
}

Tidsskriftet nr. 14/1986 var et jubileumsnummer med mange artikler om Legeforeningens rolle i samfunnet, gratulasjoner fra ulike legemiddelfirmaer og en historisk gjennomgang av foreningens strukturer. Her vises Legeforeningens generalsekretærer i perioden 1886-1986 (Tidsskr Nor Lægeforen 1986; 106: 1260).

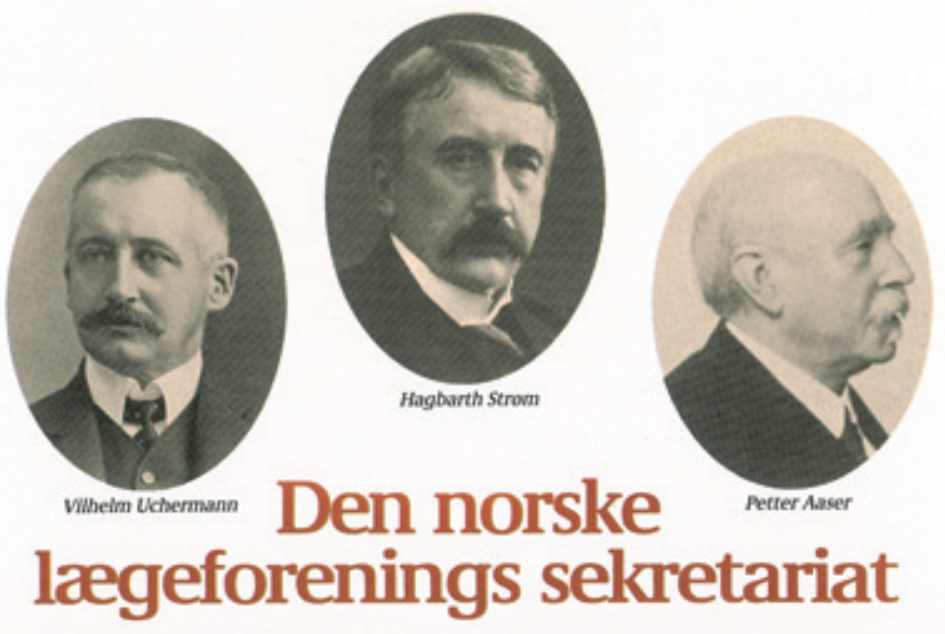

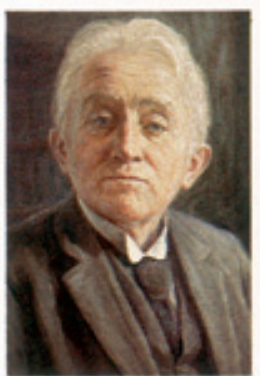

Rasmes Hansson

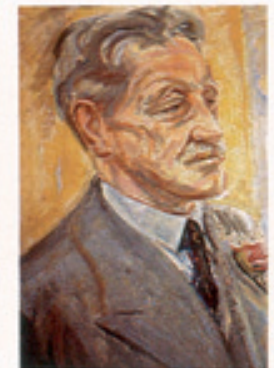

Jorgen H. Berner

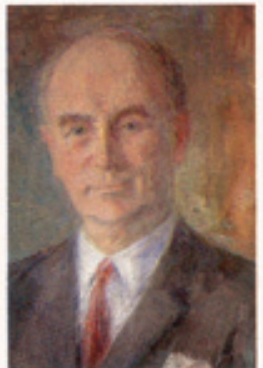

Odd Bjercke

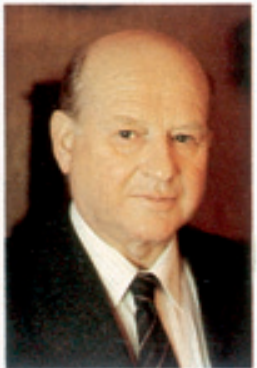

fon Skatun
Den norske lægeforening ble stiftet 6 . juli 1886, pá det forste legemotet i Kristiania. Her ble professor Joachim Andreas Voss valgt som foreningens forste president. Privatpraktiserende lege i Bergen, Klaus Hanssen, ble visepresident, og Vilhelm Uchermann ble sekretær. Marinelege Uchermann var ogsá medlem i den komité pá 16 som ble oppnevnt pá et historisk mote 22. april 1895 i Det norske medicinske Selskab, som utarbeidet forslag til lover og vedtekter for Den norske lægeforening.

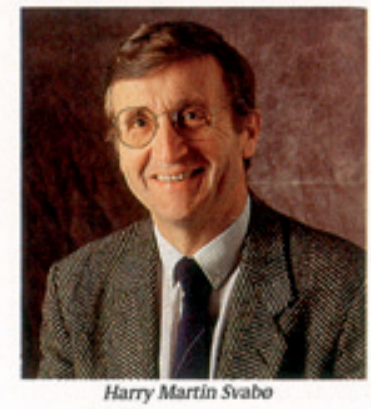

Vilhelm Uchermann. Om sekretæren heter det i vedtektenes $\S 4$ at han redigerer referatet av legemotets forhandlinger, forfatter ârsberetningen, besorger korrespondansen og offentliggjor $i$ betimelig tid for valget en fortegnelse over foreningens medlemmer. Han er tillike kasserer for foreningens midler, hvorfor han hvert ár avlegger regnskap til bestyrelsen. Et ekstrakt av regnskapet i revidert stand inntas $i$ ârsberetningen. For Sekretariatet i Den sine forretninger oppenorske lægeforening begynte sáledes med bærer sekretæren en

passende godtgjorelse. 